\title{
Mutational analysis of Portuguese families with multiple endocrine neoplasia type 1 reveals large germline deletions
}

\author{
B. M. Cavaco*, R. Domingues ${ }^{\star}$, M. C. Bacelart, \\ H. Cardoso†, L. Barrosł, L. Gomesł, M. M. A. Ruas $\ddagger$, \\ A. Agapito§, A. Garrão*, A. A. J. Pannettๆ, J. L. Silva†, \\ L. G. Sobrinho*, R. V. Thakker ๆ and V. Leite* \\ ${ }^{*}$ Centro de Investigação de Patobiologia Molecular e \\ Serviço de Endocrinologia, Instituto Português de \\ Oncologia de Francisco Gentil, Lisboa, †Serviço de \\ Endocrinologia Diabetes e Metabolismo, Hospital \\ de Santo António, Porto, $\ddagger$ Serviço de Endocrinologia \\ Diabetes e Metabolismo, Hospitais da Universidade \\ de Coimbra, Coimbra, §Serviço de Endocrinologia, \\ Hospital Curry Cabral, Lisboa, Portugal and $₫$ Molecular \\ Endocrinology Group, Nuffield Department of Clinical \\ Medicine, University of Oxford, John Radcliffe Hospital, \\ Headington, Oxford, UK
}

(Received 17 July 2001; returned for revision 25 September 2001; finally revised 12 October 2001; accepted 17 December 2001)

\section{Summary}

OBJECTIVE To determine the spectrum of MEN1 mutations in Portuguese kindreds, and identify mutationcarriers.

PATIENTS, DESIGN AND RESULTS Six unrelated MEN1 families were studied for MEN1 gene mutations by single-strand conformational polymorphism (SSCP) and DNA sequence analysis of the coding region and exon-intron boundaries of the MEN1 gene. These methods identified 4 different heterozygous mutations in four families: two mutations are novel ( $\mathrm{mt} 1539$ delG and $\mathrm{mt} 655 \mathrm{ims} 11 \mathrm{bp}$ ) and two have been previously observed (mt 735 del 46p and mt 1656 del C) all resulting in a premature stop codon. In the remaining two families, in whom no mutations or abnormal MEN1 transcripts were detected, segregation studies of the $5^{\prime}$ intragenic marker D11S4946 and codon 418 polymorphism in exon 9 revealed two large germline deletions of the MEN1 gene. Southern blot and tumour loss of heterozygosity analysis confirmed

Correspondence: Valeriano Leite MD, PhD, Serviço de Endocrinologia, Instituto Português Oncologia, Rua Professor Lima Basto, 1099-023 Lisboa, Portugal. Fax: 35121722 9895; E-mail: vleite@ipolisboa.mimsaude.pt and refined the limits of these deletions, which spanned the MEN1 gene at least from: exon 7 to the $3^{\prime}$ untranslated region, in one family, and the $5^{\prime}$ polymorphic site D11S4946 to exon 9 (obliterating the initiation codon), in the other family. Twenty-six mutant-gene carriers were identified, 6 of which were asymptomatic.

CONCLUSIONS These results emphasize the importance of the detection of MEN1 germline deletions in patients who do not have mutations of the coding region. Important clues indicating the presence of such deletions may be obtained by segregation studies using the intragenic polymorphisms D11S4946 and at codon 418. The detection of these mutations will help in the genetic counselling of clinical management of the MEN1 families in Portugal.

Multiple endocrine neoplasia type 1 (HUGO MEN1; MIM 131100; GenBank U93237) is an autosomal dominant disorder characterized by the combined occurrence of tumours of the parathyroid glands, pancreatic islet cells and anterior pituitary (Wermer, 1954; Trump et al., 1996). In addition, adrenal cortical tumours, carcinoid tumours, facial angiofibromas, collagenomas, lipomas and paragangliomas have also been described in patients with MEN1 (Trump et al., 1996; Marx, 1998). The MEN1 gene, which is located on chromosome 11q13 (Larsson et al., 1988; Thakker et al., 1989; European Consortium on MEN1, 1997a) consists of 10 exons with a 1830 bp coding region (exons 2-10) (Chandrasekharappa et al., 1997; European Consortium on MEN1, 1997b) that encode a novel 610 amino acid protein, referred to as 'MENIN' (Chandrasekharappa et al., 1997). Functional studies of the MENIN protein, which does not have homologies to other proteins (Chandrasekharappa et al., 1997), have revealed that the protein is localized primarily to the nucleus (Guru et al., 1998), and interacts directly with the N-terminus of the activating protein 1 (AP-1) transcription factor JunD, to repress JunD activated transcription (Agarwal et al., 1999).

More than 300 germline and somatic mutations of the MEN1 gene have been identified to date. These mutations are distributed throughout the coding region, suggesting that multiple domains of the protein are responsible for its biological function. However, approximately $19 \%$ of all the germline MEN1 mutations involve 
codons 83 and 84, codon 119, codons 209-211 and codons 514516 (Bassett et al., 1998; Pannett \& Thakker, 1999). Seventy-five per cent of the MEN1 mutations cause truncation of MENIN protein, probably resulting in loss of function (Pannett \& Thakker, 1999). These data, and the observation that many tumours arising in MEN1 patients show loss of heterozygosity (LOH) in 11q13 (Larsson et al., 1988; Thakker et al., 1989; Byström et al., 1990), and that overexpression of the MEN1 gene suppresses tumorigenicity of RAS-transformed NIH3T3 cells (Kim et al., 1999), are consistent with the proposal that MEN1 is a tumour suppressor gene. So far, no correlation between genotype and the clinical phenotype has been established.

In order to characterize the MEN1 gene mutations in the Portuguese population, and to identify mutation-carriers, a national consortium was established between the Portuguese endocrinology groups. Six unrelated MEN1 families were collected and analysed for MEN1 gene mutations.

\section{Patients and methods}

\section{Patients}

The diagnosis of MEN1 in the six families was based on the presence of tumours in two or more of the three main MEN1-related tissues, i.e. parathyroid, anterior pituitary and pancreatic islet cells tumours. Diagnosis of familial MEN1 required at least one first-degree relative with a MEN1-related endocrinopathy (Trump et al., 1996). Venous blood samples were obtained from 20 symptomatic members ( 9 males and 11 females, age range 12-73 years) and 19 asymptomatic members ( 3 males and 16 females, age range 6-85 years) of the six MEN1 families. Paraffin embedded tissues from 1 gastrinoma and 2 hyperplastic parathyroid glands were also obtained from patient 17 . Patients gave their informed consent to participate in this study, and the protocol was approved by the Ethics Committee of the Instituto Português de Oncologia.

\section{DNA sequence analysis of the MEN1 gene}

Genomic DNA from peripheral blood leucocytes and histological samples was extracted following standard methods (Thakker et al., 1989; Shibata, 1994). DNA sequence abnormalities of the MEN1 gene were sought for initially in the probands of the six families by single-strand conformational polymorphism analysis (SSCP) as described (Orita et al., 1989; Ainsworth et al., 1991), using previously described (European Consortium on MEN1, 1997b; Bassett et al., 1998) primers and PCR conditions. The DNA sequence of PCR products with abnormal SSCP bands was determined by manual sequencing (Pearce et al., 1995; Pearce et al., 1996). All the mutations or polymorphisms identified were confirmed by at least two independent experiments. Family members were examined for the mutations either by restrictionenzyme analysis or by SSCP or by agarose-gel electrophoresis of genomic PCR products obtained by the use of the appropriate primers. Probands from families with negative SSCPs were analysed further by direct sequencing of exons 2-10 of the MEN1 gene and of their corresponding 16 exon/intron boundaries (European Consortium on MEN1, 1997b; Bassett et al., 1998).

\section{Microsatellite polymorphism analysis}

Four polymorphic microsatellite loci from chromosome 11q13, located proximal (cen - PYGM, D11S449, D11S913 - qter) or intragenic (D11S4946) of the MEN1 gene, were used to screen for $\mathrm{LOH}$ in a gastrinoma and in two hyperplastic parathyroid glands from patient 17, as described (Thakker et al., 1989; Pang et al., 1996). LOH was defined as visible absence of an allele or a $>90 \%$ reduction in the signal for one allele in the tumour compared with the matching blood DNA. Segregation of MEN1 with the above-described polymorphic loci was also investigated in the families.

\section{mRNA analysis of the MEN1 gene}

RNA was extracted from peripheral blood lymphocytes, using TRIzol Reagent (Gibco BRL, Gaithersburg, USA) following the manufacturer's instructions. Complementary DNA (cDNA) was then synthesized using random primers (Gibco BRL, Gaithersburg, USA) and SuperScript II reverse transcriptase (Gibco BRL, Gaithersburg, USA) according to the protocols recommended by the manufacturer. Primers were devised to amplify 4 overlapping cDNA segments (nts 114-753, 633-1061, 1001-1474, 14281972) covering the entire MEN1 coding region (exons 2 through 10). Primer sequences and reaction conditions are available upon request. The resultant RT-PCR products were separated by agarose gel electrophoresis.

\section{Southern blot analysis}

Fifteen micrograms of genomic DNA, from individuals of families with no detectable mutations and from 10 healthy controls, were cleaved with KpnI, SmaI, SacI and SacII (New England Biolabs, Beverly, USA) and Southern blot analysis using Hybond $\mathrm{N}+$ nylon membranes (Amersham Pharmacia Biotech, Buckinghamshire, UK), and ${ }^{32} \mathrm{P}$-labelled probes corresponding to GAPDH (human glyceraldehyde-3-phosphate dehydrogenase) cDNA segment (nts 2606-2935), and two MEN1 cDNA segments $\alpha$ and $\beta$ (nts 152-753 and 1012-1474, covering exons 2 and 3 and $7-10$, respectively) was performed as described previously (Pang et al., 1996). Primer sequences and reaction conditions are available upon request. Densitometric analysis of the band intensities was performed using the ONE-Dscan software (Scanalytics, Division 
of CSPI, USA). The corrected intensities of the restriction fragments detected with the MEN1 probe were obtained calculating the ratio between the intensity of the fragment detected with the MEN1 probe and the intensity of the fragment detected with the GAPDH probe.

\section{Results}

\section{Clinical findings}

Six unrelated Portuguese families were examined for MEN1 germline mutations. The clinical characteristics are summarized in Table 1. The occurrence of tumours in the three major systems in the 26 MEN1 gene mutant carriers examined in this study was $17 / 26(65 \%)$ for the parathyroids, $10 / 26(38 \%)$ for the anterior pituitary and 11/26 (42\%) for enteropancreatic neuroendocrine tissues.

\section{Germline mutations}

The analysis of SSCPs obtained from the study of the six probands revealed four abnormal patterns of bands. DNA sequence analysis of these four SSCP abnormalities revealed four MEN1 germline mutations in patients 1, 5, 11 and 14 (Table 1). These mutations were heterozygous, and consisted of: two previously described deletions (nt1656delC in exon 10 and nt735del4bp in exon 3) (Agarwal et al., 1997; Bassett et al., 1998) found in patients 1 and 5, respectively; and two new mutations that consisted of an 11-bp insertion in exon 3 (nt655ins11bp), which leads to a frameshift that results in five missense amino acids followed by a premature stop codon, found in patient 11 (Fig. 1); and a deletion in exon 10 (nt1539delG), which leads to a frameshift that results in 81 missense amino acids followed by a premature stop codon, found in patient 14 (Table 1). All mutations were verified by direct sequencing of both strands. The $11 \mathrm{bp}$ insertion at codon 182, exon 3, was confirmed by agarose gel electrophoresis (Fig. 1b). Furthermore, this mutation creates a new restriction site for the enzyme $B s r I$, and this facilitated an independent confirmation of the insertion. The four base pair deletion in exon 3, nt735 was also confirmed by gel electrophoresis, as it resulted in heteroduplex formation. The deletion of a $\mathrm{G}$ on codon 477, exon 10, abolished a restriction site of the enzyme SmaI (CCC/GGG) and this was used to confirm the mutation. In families 1-4, segregation studies, SSCP, restriction digest analysis or agarose gel electrophoresis of PCR products from other family members confirmed that the mutations co-segregated with the disease state. In total, 27 members were examined with these methods. All the 12 affected members had MEN1 gene mutations. In the remaining 15 members who were clinically and biochemically unaffected, four were found to harbour MEN1 mutations (age range 12-17 years) and the remaining 11 members had no mutations. The young ages of the four mutant gene carriers is consistent with the reported age-related penetrance of MEN1 (Trump et al., 1996; Bassett et al., 1998).

\section{Intragenic deletions}

In families 5 and 6 , mutations were not detected by direct DNA sequence analysis of exons 2-10 of the MEN1 gene and of their corresponding 16 exon/intron boundaries. In these probands we also searched for abnormal mRNA transcripts because our sequencing analysis of the MEN1 gene would not include the branch sites, which are conserved intronic sequences known to be functionally important to form the lariat-shaped structure in the mechanism of splicing. RT-PCR analysis of MEN1 gene mRNA, in both families, did not detect abnormalities. In order to confirm that the disease gene was located on chromosome 11q13, we performed haplotype analysis and this demonstrated co-segregation of PYGM, D11S449, D11S913 with MEN1 in these families. However, in family 6 a deletion of the maternal allele involving the intragenic locus D11S4946 was detected (Fig. 2a). To assess further the extent of this deletion, we analysed by SSCP and direct sequencing, the segregation of a commonly described exon 9 polymorphism D418D (GAC $\rightarrow \mathrm{GAT})$. This confirmed the absence of the maternal polymorphic sequence (GAT) in individual 25 from family 6 (Fig. 2b). Southern blot analysis of individuals from family 6 and 10 healthy controls did not reveal abnormal restriction fragment length polymorphisms (RFLPs) (Table 2). However, the corrected intensities of the restriction fragments in the three affected and two asymptomatic individuals, previously suspected to be carriers (25 and 26), were approximately $1: 2$ of that in the normal controls, thus confirming the hemizygosity of the MEN1 gene. Taken together, these findings indicate that the large germline deletion in family 6 is $>6 \mathrm{~kb}$ in size, spanning the MEN1 gene from the $5^{\prime}$ polymorphic site D11S4946 at least to exon 9 (Fig. 3). This deletion is $<600 \mathrm{~kb}$ in size, because heterozygosity of the sites D11S449 ( $\sim 500 \mathrm{~kb}$ telomeric) and PYGM ( $\sim 55 \mathrm{~kb}$ centromeric) is retained (European Consortium on MEN1, 1997a, 1997b).

In family 5, heterozygosity was retained for the D11S4946 locus (data not shown). An analysis of the exon 9 polymorphism, by SSCP and direct DNA sequencing, revealed a deletion of the maternal sequence (GAC) in patient 21 (Fig. 4). Southern blot analysis of family 5, with probe $\alpha$, which covers exons 2 and 3, together with SacI and SmaI (Fig. 3), revealed different RFLPs, with $3.3 \mathrm{~kb}$ and $5.7 \mathrm{~kb}$, respectively, in the affected individuals, which were not present in 10 healthy controls (Fig. 5, Table 2). Conversely, these abnormal RFLPs were not observed using probe $\beta$, which covers exons 7-10 (Fig. 3), suggesting that these exons are lost (Table 2). These findings are supported by the above-described loss of exon 9. Southern blot analysis with SacII 
Table 1 Patients with MEN1 gene mutations and associated phenotypes

\begin{tabular}{|c|c|c|c|c|c|c|c|c|c|c|c|c|}
\hline \multirow[b]{2}{*}{ Family } & \multirow[b]{2}{*}{ Patient no. } & \multirow[b]{2}{*}{ Pedigree } & \multirow[b]{2}{*}{ Age* } & \multirow[b]{2}{*}{ Sex } & \multicolumn{4}{|l|}{ Phenotype } & \multicolumn{4}{|c|}{ MEN1 germline mutation } \\
\hline & & & & & Parathyroid & Anterior pituitary & Enteropancreatic & Other & Exon & Codon & Mutation & Predicted effect \\
\hline \multirow[t]{4}{*}{1} & 1 & Index $\dagger$ & 38 & M & $\uparrow \mathrm{Ca}^{* *}$ & $\begin{array}{l}\text { Macroaden } \\
\text { (+ PRL, + GH) }\end{array}$ & Panc gastrinoma & Lung carcinoid§ & 10 & 516 & nt $1656 \mathrm{delC}$ & fs $42 \mathrm{aaX}$ \\
\hline & 2 & D1 & 14 & $\mathrm{~F}$ & - & - & - & - & & & & \\
\hline & 3 & B1 & 40 & $\mathrm{M}$ & HPT & - & - & - & & & & \\
\hline & 4 & D3 & 19 & $\mathrm{~F}$ & HPT & - & - & - & & & & \\
\hline \multirow[t]{6}{*}{2} & 5 & Index & 20 & M & HPT & Macroprolactinoma & - & - & 3 & $209-210$ & nt 735del4bp & fs $13 a a X$ \\
\hline & 6 & $\mathrm{Si} 5$ & 17 & $\mathrm{~F}$ & - & - & - & - & & & & \\
\hline & 7 & B5 & 12 & $\mathrm{M}$ & $\uparrow \mathrm{PTH}$ & - & - & - & & & & \\
\hline & 8 & Mo5 & 43 & $\mathrm{~F}$ & HPT & $\begin{array}{l}\text { Macroaden } \\
(+\mathrm{PRL},+\mathrm{GH})\end{array}$ & Malignant insulinoma§ & - & & & & \\
\hline & 9 & B8 & 40 & M & HPT (3 Ad§) & 1 Cyst & $\begin{array}{l}\text { Multiple panc tumours } \\
( \pm \text { INS) }\end{array}$ & Adrenal hyp, goitre & & & & \\
\hline & 10 & S9 & 12 & M & - & - & 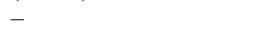 & - & & & & \\
\hline \multirow[t]{3}{*}{3} & 11 & Index & 44 & $\mathrm{~F}$ & HPT (Hyp 4 glands§) & Microprolactinoma & - & - & $\rightarrow 3$ & 182 & nt 655 ins $11 \mathrm{bp}$ & fs $5 a a X$ \\
\hline & 12 & S11 & 21 & M & HPT & - & - & - & & & & \\
\hline & 13 & D11 & 15 & $\mathrm{~F}$ & - & - & - & - & & & & \\
\hline \multirow[t]{3}{*}{4} & 14 & Index & 52 & $\mathrm{~F}$ & HPT & $\begin{array}{l}\text { Microaden } \\
\text { (nonproducing) }\end{array}$ & $\begin{array}{l}\text { Malignant panc } \\
\text { gastrinoma\& }\end{array}$ & Adrenal hyp, angiof & $\rightarrow 10$ & 477 & nt $1539 \mathrm{delG}$ & fs $81 \mathrm{aaX}$ \\
\hline & 15 & $\mathrm{Fa} 14 \dagger$ & 60 & M & - & - & Subtotal gastrectomy & Larynx carcinoma§ & & & & \\
\hline & 16 & D14 & 26 & $\mathrm{~F}$ & - & Macroprolactinoma & - & - & & & & \\
\hline \multirow[t]{5}{*}{5} & 17 & Index & 41 & M & HPT (Hyp 4 glands§) & - & Panc gastrinoma & $\begin{array}{l}\text { Angiof, thymic } \\
\text { carcinoid§ }\end{array}$ & \multirow{5}{*}{\multicolumn{4}{|c|}{$\rightarrow$ del [Exon 7-3' untranslated region] }} \\
\hline & 18 & Si17 & 32 & $\mathrm{~F}$ & HPT & - & - & - & & & & \\
\hline & 19 & Mo17 & 59 & $\mathrm{~F}$ & HPT & $-\Phi$ & Hypergastrinaemia & - & & & & \\
\hline & 20 & Si19 & 73 & $\mathrm{~F}$ & HPT & - & $\begin{array}{l}\text { Panc endoc tumour } \\
\text { (nonproducing) }\end{array}$ & - & & & & \\
\hline & 21 & $\mathrm{~S} 20 \dagger$ & 48 & M & HPT (1 Ad§) & $\begin{array}{l}\text { Macroaden } \\
\text { (nonproducing)§ }\end{array}$ & $\begin{array}{l}\text { Gastrectomy } \\
\text { Multiple gastric and } \\
\text { duod gastrinomas§ } \\
\text { Panc endoc carcinoma } \\
\text { (nonproducing)§ }\end{array}$ & Adrenal hyp & & & & \\
\hline \multirow[t]{5}{*}{6} & 22 & Index & 56 & $\mathrm{~F}$ & HPT (Hyp 4 glands§) & $\begin{array}{l}\text { Microaden } \\
\text { (nonproducing) }\end{array}$ & - & Lung carcinoid§ & \multirow{5}{*}{\multicolumn{4}{|c|}{$\rightarrow \operatorname{del}\left[5^{\prime}(\mathrm{D} 11 \mathrm{~S} 4946)-\right.$ exon 9] }} \\
\hline & 23 & $\mathrm{Si} 22$ & 51 & $\mathrm{~F}$ & HPT (Hyp 4 glands§) & $\begin{array}{l}\text { Microaden } \\
\text { (nonproducing) }\end{array}$ & Hypergastrinaemia & Adrenomyelolipoma & & & & \\
\hline & 24 & $\mathrm{Si} 22$ & 41 & $\mathrm{~F}$ & HPT (Hyp 4 glands§) & $\begin{array}{l}\text { Macroaden } \\
\text { (nonproducing)§ }\end{array}$ & $\begin{array}{l}\text { Multiple glucagonomas } \\
(+ \text { GLUC },+ \text { PP }) \S\end{array}$ & - & & & & \\
\hline & 25 & D23 & 22 & $\mathrm{~F}$ & - & - & - & - & & & & \\
\hline & 26 & D23 & 27 & $\mathrm{~F}$ & - & - & - & - & & & & \\
\hline
\end{tabular}


11 bp Insertion (codon 182) exon 3

(a)

\begin{tabular}{|c|c|c|c|c|c|c|c|}
\hline Codon number & 182 & 183 & 184 & 185 & 186 & 187 & 188 \\
\hline $\begin{array}{r}\text { Amino acid (WT) } \\
(\mathrm{m})\end{array}$ & $\begin{array}{l}\text { Ala } \\
\text { Ala }\end{array}$ & $\begin{array}{l}\text { Trp } \\
\text { Asn }\end{array}$ & $\begin{array}{l}\text { Val } \\
\text { Thr }\end{array}$ & $\begin{array}{l}\text { Val } \\
\text { Thr }\end{array}$ & $\begin{array}{l}\text { Phe } \\
\text { Thr }\end{array}$ & $\begin{array}{l}\text { Gly } \\
\text { Gly }\end{array}$ & $\begin{array}{l}\text { Pro } \\
\text { Stop }\end{array}$ \\
\hline Wild type (WT) & $\mathrm{GC}$ & & & & & $\mathrm{GG}$ & $\mathrm{CCC}$ \\
\hline
\end{tabular}

(b)

\section{Family 3} $M E N 1$ gene in family 3 . Below each symbol is the individual's number according to Table 1. Agarose gel electrophoresis, SSCP and DNA sequence analysis of individuals 11,12 and 13 revealed an 11-bp insertion (insAAACACTACTA) at the second position of codon 182. This insertion is predicted to cause a frameshift that continues to codon 187 , before a stop codon (TAG) is encountered (a). The $11 \mathrm{bp}$ insertion could be visualized directly on a $3 \%$ agarose gel stained with ethidium bromide as the mutant (m) PCR product is $201 \mathrm{bp}$ whereas the wild-type (WT) product is $190 \mathrm{bp}$. The mutant-gene carriers (11, 12 and 13) were heterozygous, and individual I.2 was homozygous for the wild-type sequence. N1, $\mathrm{N} 2$ and N3 are 3 unrelated normal individuals (b). Direct sequencing of exon 3 shows an 11-bp insertion in the mutant allele. The insertion point is indicated by an arrow, and the inserted bases (INS) are shown (c). Individuals are represented as male (squares), female (circles), unaffected (unblackened/unmarked symbols), affected with hyperparathyroidism (symbols with blackened upper-left quadrant), affected with enteropancreatic tumour(s) (symbols with blackened lower-left quadrant), affected with anterior pituitary tumour(s) (symbols with blackened upper-right quadrant), affected with other MEN1 lesions (symbols with blackened lower-right quadrant), and unaffected mutant-gene carriers (symbols containing a black dot).
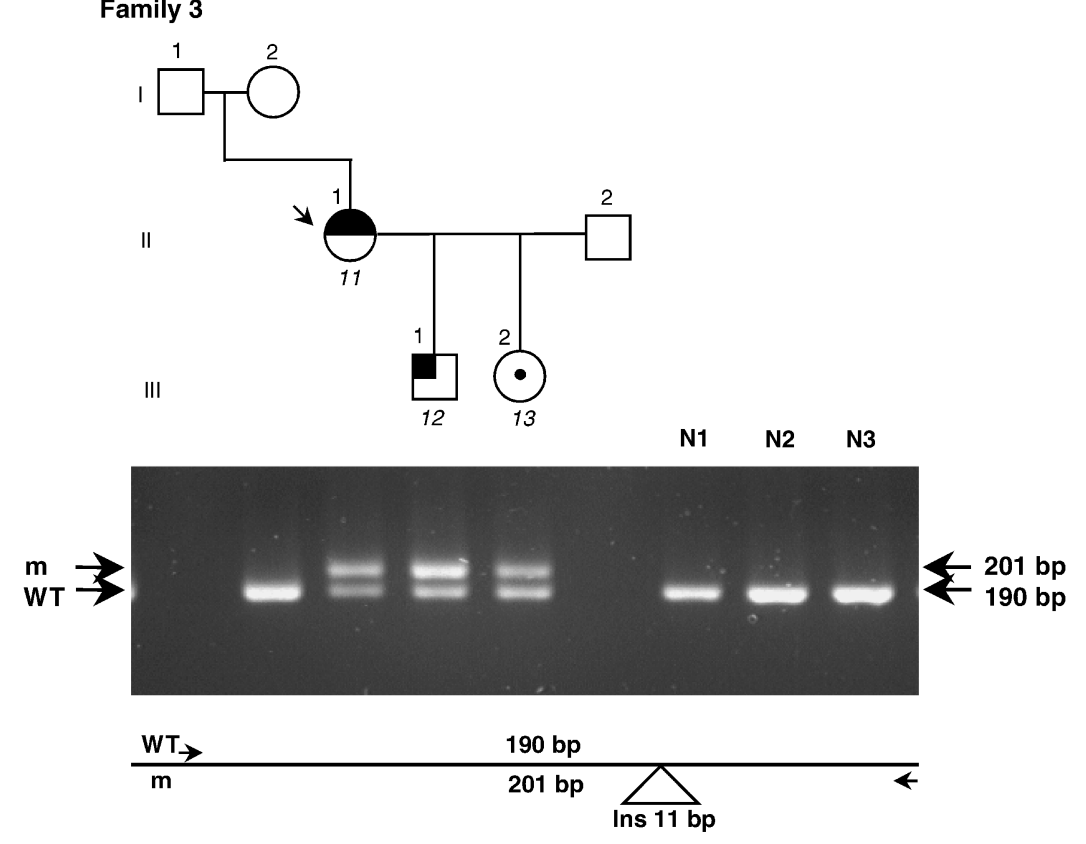

(c)

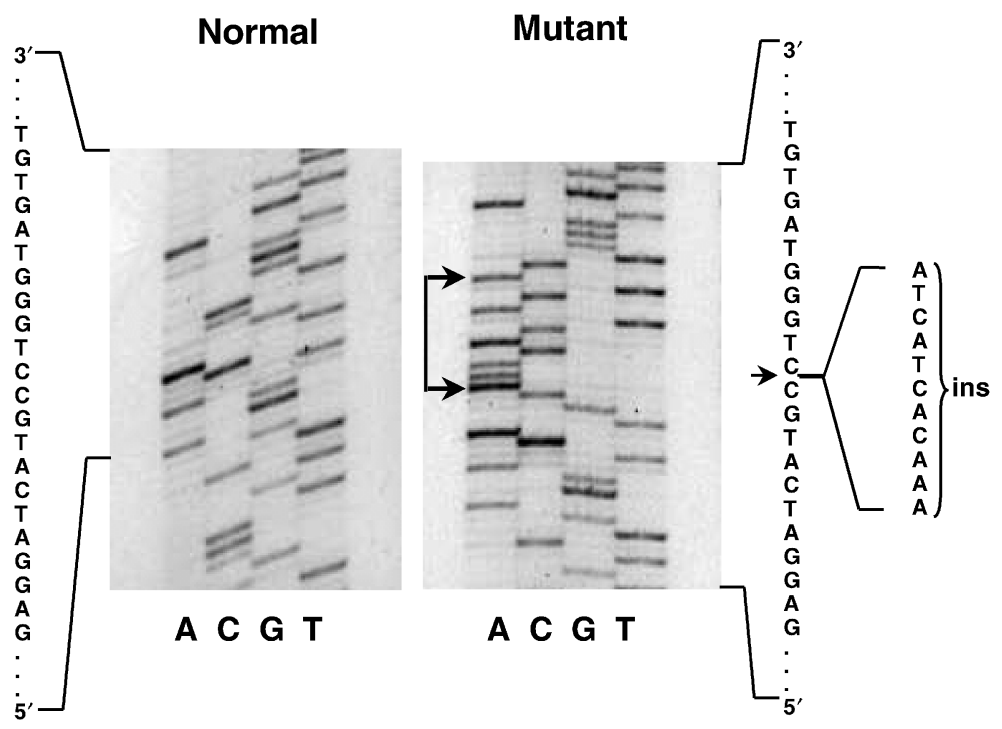




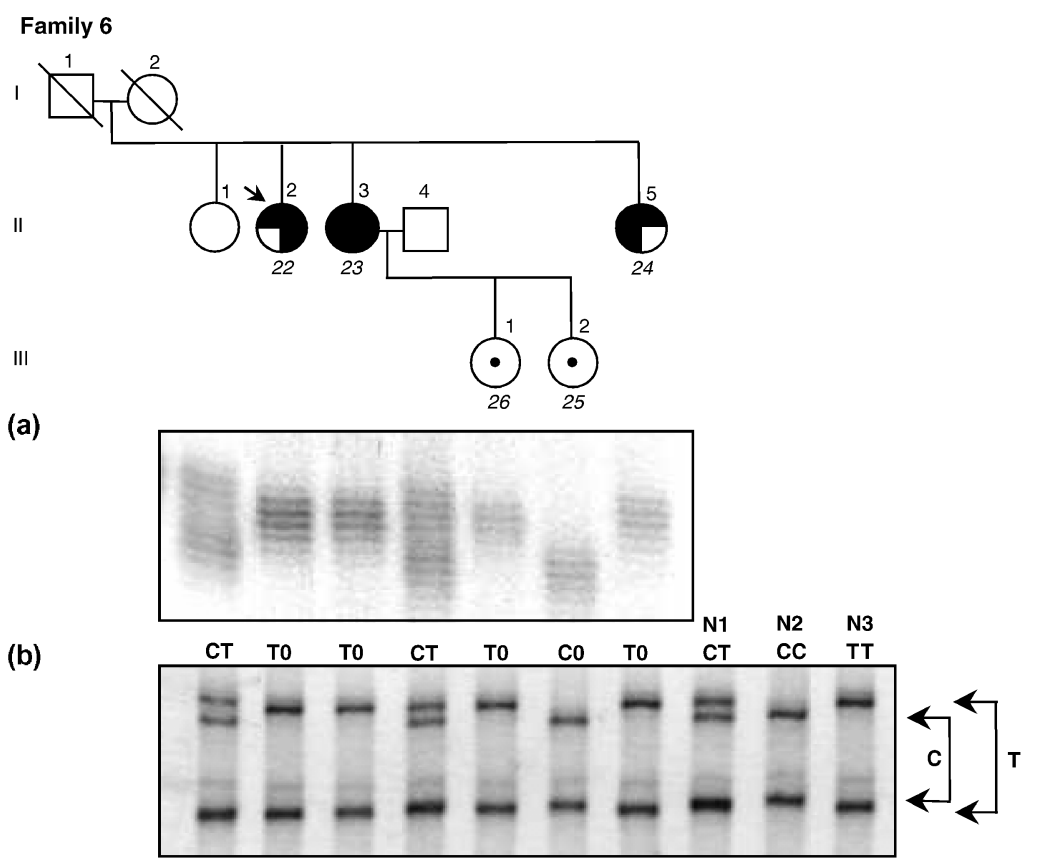

Fig. 2 Detection of a large germline deletion of the $M E N 1$ gene in family 6. Below each symbol is the individual's number according to Table 1 . Segregation studies, with the $5^{\prime}$ intragenic locus D11S4946, revealed the absence of the maternal allele in patient 25 from family 6 (a). Segregation studies, performed by SSCP, of exon 9 polymorphism D418D $(\mathrm{GAC} \rightarrow \mathrm{GAT})$, revealed also the absence of the maternal polymorphic sequence (GAT) in individual 25 , which is represented by the symbol 0 (b). Codon 418 and D11S4946 locus were probably also absent in individual 26, the sister of the former, as segregation studies with MEN1 polymorphic flanking markers showed that she received the same maternal chromosome (data not shown). Hemizygosity for these loci was also found in the other affected individuals. N1, N2 and N3, are 3 unrelated normal individuals. The symbols for individuals are as indicated in Fig. 1.
Table 2 MEN1 RFLPs studies in families 5 and 6

\begin{tabular}{|c|c|c|c|c|c|c|}
\hline \multirow{3}{*}{$\begin{array}{l}\text { Restriction } \\
\text { enzyme }\end{array}$} & \multicolumn{6}{|c|}{ Fragment sizes $(\mathrm{kb})$} \\
\hline & \multicolumn{3}{|c|}{ Probe $\alpha$} & \multicolumn{3}{|c|}{ Probe $\beta$} \\
\hline & F5 & F6 & $\mathrm{N}$ & F5 & F6 & $\mathrm{N}$ \\
\hline KpnI & $3 \cdot 7$ & $3 \cdot 7$ & $3 \cdot 7$ & $5 \cdot 0$ & $5 \cdot 0$ & $5 \cdot 0$ \\
\hline \multirow[t]{3}{*}{ SacI } & $3 \cdot 7$ & $3 \cdot 7$ & $3 \cdot 7$ & $1 \cdot 0$ & $1 \cdot 0$ & $1 \cdot 0$ \\
\hline & $8 \cdot 6$ & $8 \cdot 6$ & $8 \cdot 6$ & $9 \cdot 1$ & $9 \cdot 1$ & $9 \cdot 1$ \\
\hline & $3 \cdot 3$ & & & & & \\
\hline \multirow[t]{2}{*}{ SacII* } & $7 \cdot 3$ & $7 \cdot 3$ & $7 \cdot 3$ & $7 \cdot 3$ & $7 \cdot 3$ & $7 \cdot 3$ \\
\hline & $0 \cdot 4$ & $0 \cdot 4$ & $0 \cdot 4$ & $0 \cdot 4$ & $0 \cdot 4$ & $0 \cdot 4$ \\
\hline \multirow[t]{2}{*}{ SmaI } & $6 \cdot 1$ & $6 \cdot 1$ & $6 \cdot 1$ & $6 \cdot 1$ & $6 \cdot 1$ & $6 \cdot 1$ \\
\hline & $5 \cdot 7$ & & & & & \\
\hline
\end{tabular}

F, mutant MENI gene carriers from family; N, normal control

individuals; *in this Southern blot probes $\alpha$ and $\beta$ were used together.

and KpnI did not reveal abnormal MEN1 RFLPs (Table 2). These combined data indicate that the deletion begins after $\mathrm{SacI}$ restriction site on exon 2 and probably spans the $3^{\prime}$ untranslated region of the MEN1 gene (Fig. 3). In order to refine the limits of this deletion, mapping studies, using MEN1 exon specific PCR primers, of a gastrinoma and two parathyroid hyperplastic glands from patient 17 (family 5), which showed loss of heterozygosity involving the wild-type allele in all 11q13 studied loci (data not shown), were undertaken. This revealed the presence of PCR products from exons $2-6$ but an absence of PCR products from exons 7-10. These data from the MEN1 tumours indicate that the mutated allele lacks the region containing exons 7-10 and extends in the $3^{\prime}$ untranslated region (Fig. 3); thus the germline deletion in family 5 is $>3 \mathrm{~kb}$ in size. The MEN1 gene is transcribed from telomere to the centromere (Kishi et al., 1998), and as heterozygosity at PYGM locus, which is $\sim 55 \mathrm{~kb}$ away, is retained, this deletion is likely to be $<55 \mathrm{~kb}$ in size.

In total, 12 members from family 5 and 6 , with no mutations detected by PCR-based sequencing analysis, were examined with these alternative methods. All of the eight affected members had large germline deletions of the MEN1 gene. In the remaining four members, who were clinically and biochemically normal, two were found to have MEN1 gene deletions. The ages of these two mutant gene carriers were 22 and 27 years, and this is consistent with the reported (Trump et al., 1996; Bassett et al., 1998) agerelated penetrance for $M E N 1$.

\section{Discussion}

Our study of six Portuguese kindreds with MEN1 has identified six mutations (Table 1), and four of these represent novel abnormalities. These four new mutations consist of two large deletions, one $11 \mathrm{bp}$ insertion (nt655ins $11 \mathrm{bp}$ ), and a single base pair deletion (nt1539delG). The two other mutations that consisted of a 4-bp (nt735del4bp) and a 1-bp (nt1656delC) deletion have been previously observed in other unrelated kindreds (Agarwal et al., 1997; Bassett et al., 1998). Our finding of the two large deletions is of significance as it is important to realize that such deletions will remain undetectable by the usual methods that are used to search for mutations, e.g. SSCP, direct DNA sequence, and 
Fig. 3 Large germline deletions in families 5 and 6. Positions in the MEN1 gene of the sequences recognized by the restriction enzymes used in the Southern blot analysis, and MEN1 exonic sequences detected by probes $\alpha$ and $\beta$, are shown. In family 5 , the deletion starts somewhere after exon 6 and extends in the $3^{\prime}$ untranslated region. In family 6 , the deletion spans the $5^{\prime}$ polymorphic site D11S4946 and extends at least to exon 9 .
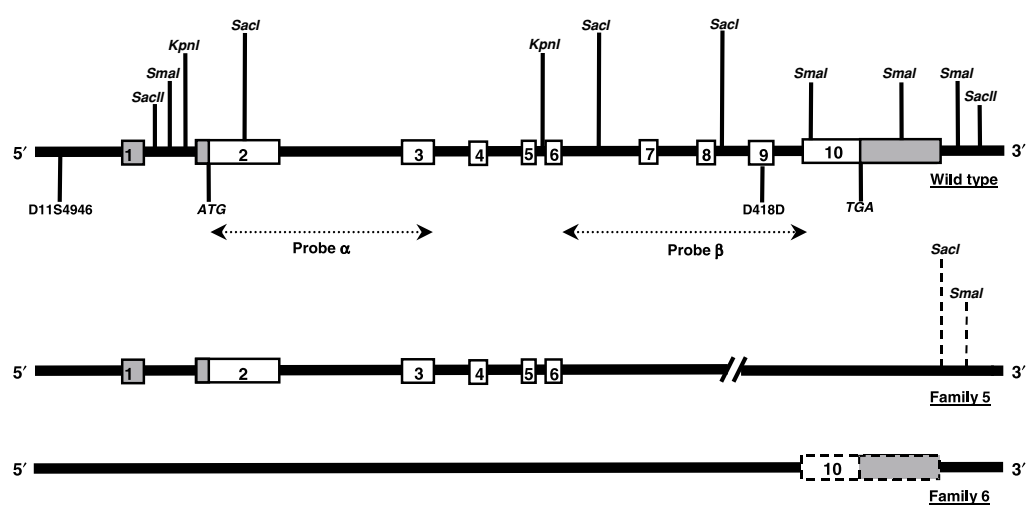
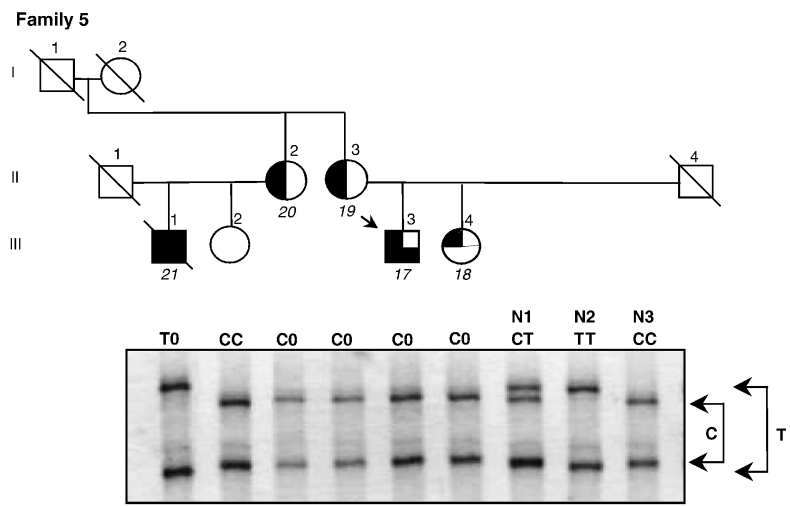

Fig. 4 Detection of a large germline deletion of the MEN1 gene in family 5. Below each symbol is the individual's number according to Table 1. Segregation studies, performed by SSCP, of exon 9 polymorphism $\mathrm{D} 418 \mathrm{D}(\mathrm{GAC} \rightarrow \mathrm{GAT})$, showed a deletion of the maternal sequence (GAC) in patient 21 , which is represented by the symbol 0 . Hemizygosity for this locus was also found in the other affected individuals. Individual III.2 is not a carrier of the mutated allele, as segregation studies with D11S4946 and MEN1 polymorphic flanking markers, and also Southern blot analysis, showed that she received the wild-type maternal chromosome (data not shown). N1, N2 and N3, are 3 unrelated normal individuals. The symbols for individuals are as indicated in Fig. 1.

RT-PCR analysis. Moreover, by using such methods it has been established that in $6 \%$ to $14 \%$ of the MEN1 families MEN1 mutations will not be detected (Agarwal et al., 1997; Chandrasekharappa et al., 1997; Bassett et al., 1998; Giraud et al., 1998). Indeed, a sole reliance on these methods in our small series of six families would have resulted in a failure to detect abnormalities of the coding region in $33 \%$ of the families. It has been suggested that such MEN1 families may harbour mutations in the regulatory or untranslated regions, or that may have hypermethylation of the GC-rich sequences of the $5^{\prime}$ region (Agarwal et al., 1997; Bassett et al., 1998; Giraud et al., 1998). In addition, such MEN1 families may have germline deletions as illustrated

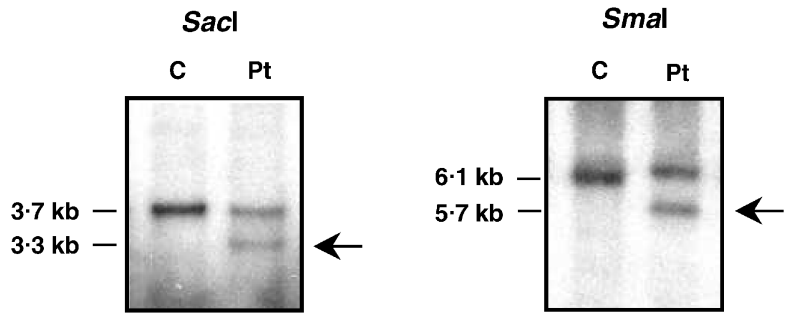

Fig. 5 MEN1 specific RFLPs detected by Southern blot analysis of DNA from an affected individual from family 5 . The approximate sizes of the RFLPs were calculated using a standard curve derived from the molecular size marker Lambda DNA-HindIII Digest. Probe $\alpha$, which spans exons 2-3, detected a 3·3-kb SacI RFLP and a 5·7-kb SmaI RFLP (indicated by an arrow) in the affected individual $(\mathrm{Pt})$, but not in the unaffected control (C) (Table 2). These results confirm that this patient carries a large germline deletion. Identical results were obtained with the other affected individuals from this family.

by our studies (Table 1, Fig. 3) of families 5 (Fig. 4) and 6 (Fig. 2). In detecting these germline mutations, we obtained important clues by examining the polymorphisms at codon 418 in exon 9, and by using microsatellite polymorphisms. Furthermore, Southern blot, and the analysis of tumours which had loss of heterozygosity involving the wild-type allele and which therefore facilitated the detection of the mutant allele, helped to provide a confirmation of the germline deletions. The exact size of these germline deletions is difficult to establish, but our studies indicate that the deletion in family 5 may range between 3 and $55 \mathrm{~kb}$, and that in family 6 may range from 6 to $600 \mathrm{~kb}$. Such germline deletions, which have been reported previously in only two other families (Kishi et al., 1998; Bergman et al., 2000), are likely to be more common than suspected hitherto, particularly as they may have been missed by the usual methods of mutational analysis. In regard to this, the careful examination of the codon 418 polymorphism, the use of microsatellite polymorphisms, and the utilization of MEN1 RFLPs as illustrated by our results will help to identify these germline deletions. The molecular 
mechanisms that lead to these germline deletions remain to be elucidated, but it is important to note that the patients and families with these large germline deletions did not have more severe phenotypes when compared to those with smaller deletions or point mutations (Table 1). The molecular mechanisms causing the smaller deletions are likely to be associated with flanking DNA sequence repeats, which can give rise to a slipped-mispairing at the replication fork, during replication, followed by nucleotide excision as has been reported for the nt $1656 \mathrm{delC}$ and $\mathrm{nt} 735 \mathrm{del} 4 \mathrm{bp}$ mutations (Krawczak \& Cooper, 1991; Bassett et al., 1998). The same mechanism may explain the deletion of one $G$ at codon 477 , detected in family 4 . The nucleotide sequence flanking codon 477 is GC-rich, which is also known to correlate with a high deletion frequency (Krawczak \& Cooper, 1991), probably as a result of the increased stabilization of deletion intermediates facilitating slipped-mispairing. Indeed, it is of interest to note that an insertion of one $\mathrm{G}$ has also been reported (Poncin et al., 1999) at this precise site. Furthermore, the size and position of insertions are reported (Cooper \& Krawczak, 1991) to be non-random, and highly dependent upon the surrounding DNA sequence, as in the deletional mechanisms of mutagenesis. This is well illustrated by the $11 \mathrm{bp}$ insertion in exon 3, found in family 3 (Table 1), in which nine of the $11 \mathrm{bp}$ inserted in the mutated DNA sequence (lower-case letters), if read in the antisense direction, are complementary to a neighbouring nucleotide sequence, as follows:

\section{5' ... ATGCaaacactactaCTGGGTAGTGT T TGGGCCCAATG ... 3’.}

Interestingly, the finding of six different mutations in these Portuguese families confirms their unrelatedness and the absence of a founder effect in the Portuguese population. Furthermore, the younger ages of the asymptomatic, biochemically normal mutant gene carriers confirms the age-related penetrance of this disorder, and our results will help in the genetic counselling and management of these patients.

\section{Acknowledgements}

We are grateful for support to Liga Portuguesa Contra o Cancro NRS, Instituto Português de Oncologia de Francisco Gentil, Lisbon, to POCTI (FCT), Portugal (BMC, RSD, LGS, VL) and to the Medical Research Council, UK (AAJP and RVT). We thank our colleagues Cristina Lobato and Carlos Fernandes who provided blood samples and clinical information.

\section{References}

Agarwal, S.K., Guru, S.C., Heppner, C., Erdos, M.R., Collins, R.M., Park, S.Y., Saggar, S., Chandrasekharappa, S.C., Collins, F.S., Spiegel, A.M., Marx, S.J. \& Burns, A.L. (1999) Menin interacts with the AP1 transcription factor JunD and represses JunD-activated transcription. Cell, 84, 730-735.
Agarwal, S.K., Kester, M.B., Debelenko, L.V., Heppner, C., EmmertBuck, M.R., Skarulis, M.C., Doppman, J.L., Kim, Y.S., Lubensky, I.A., Zhuang, Z., Green, J.S., Guru, S.C., Manickam, P., Olufemi, S.E., Liotta, L.A., Chandrasekharappa, S.C., Collins, F.S., Spiegel, A.M., Burns, A.L. \& Marx, S.J. (1997) Germline mutations of the MEN1 gene in familial multiple endocrine neoplasia type 1 and related states. Human Molecular Genetics, 6, 1169-1175.

Ainsworth, P.J., Surh, L.C. \& Coulter, M.M.B. (1991) Diagnostic single strand conformational polymorphism, (SSCP): a simplified nonradioisotopic method as applied to a Tay-Sachs B1 variant. Nucleic Acids Research, 19, 405-406.

Bassett, J.H.D., Forbes, S.A., Pannett, A.A.J., Lloyd, S.E., Christie, P.T., Wooding, C., Harding, B., Besser, G.M., Edwards, C.R., Monson, J.P., Sampson, J., Wass, J.A., Wheeler, M.H. \& Thakker, R.V. (1998) Characterization of mutations in patients with multiple endocrine neoplasia type 1. American Journal of Human Genetics, 62, 232-244.

Bergman, L., Teh, B., Cardinal, J., Palmer, J., Walters, M., Shepherd, J., Cameron, D. \& Hayward, N. (2000) Identification of MEN1 gene mutations in families with MEN1 and related disorders. British Journal of Cancer, 83, 1009-1014.

Byström, C., Larsson, C., Blomberg, C., Sandelin, K., Falkmer, U., Skogseid, B., Oberg, K., Werner, S. \& Nordenskjold, M. (1990) Localization of the MEN1 gene to a small region within chromosome 11q13 by deletion mapping in tumors. Proceedings of the National Academy of Sciences USA, 87, 1968-1972.

Chandrasekharappa, S.C., Guru, S.C., Manickam, P., Olufemi, S.E., Collins, F.S., Emmert-Buck, M.R., Debelenko, L.V., Zhuang, Z., Lubensky, I.A., Liotta, L.A., Crabtree, J.S., Wang, Y., Roe, B.A., Weisemann, J., Boguski, M.S., Agarwal, S.K., Kester, M.B., Kim, Y.S., Heppner, C., Dong, Q., Spiegel, A.M., Burns, A.L. \& Marx, S.J. (1997) Positional cloning of the gene for multiple endocrine neoplasia-type 1. Science, 276, 404-407.

Cooper, D.N. \& Krawczak, M. (1991) Mechanisms of insertional mutagenesis in human genes causing genetic disease. Human Genetics, 87, 409-415.

European Consortium on MEN1 (1997a) Construction of a 1.2-Mb sequence-ready contig of chromosome $11 \mathrm{q} 13$ encompassing the multiple endocrine neoplasia type 1 (MEN1) gene. Genomics, 44, 94 100.

European Consortium on MEN1 (1997b) Identification of the multiple endocrine neoplasia type 1 (MEN1) gene. Human Molecular Genetics, 6, 1177-1183.

Giraud, S., Zhang, C.X., Serova-Sinilnikova, O., Wautot, V., Salandre, J., Buisson, N., Waterlot, C., Bauters, C., Porchet, N., Aubert, J.P., Emy, P., Cadiot, G., Delemer, B., Chabre, O., Niccoli, P., Leprat, F., Duron, F., Emperauger, B., Cougard, P., Goudet, P., Sarfati, E., Riou, J.P., Guichard, S., Rodier, M., Meyrier, A., Caron, P., Vantyghem, M.C., Assayag, M., Peix, J.L., Pugeat, M., Rohmer, V., Vallotton, M., Lenoir, G., Gaudray, P., Proye, C., Conte-Devolx, B., Chanson, P., Shugart, Y.Y., Goldgar, D., Murat, A. \& Calender, A. (1998) Germline mutation analysis in patients with multiple endocrine neoplasia type 1 and related disorders. American Journal of Human Genetics, 63, 455-467.

Guru, S.C., Goldsmith, P.K., Burns, A.L., Marx, S.J., Spiegel, A.M., Collins, F.S. \& Chandrasekharappa, S.C. (1998) Menin, the product of the MEN1 gene, is a nuclear protein. Proceedings of the National Academy of Sciences USA, 95, 1630-1634.

Kim, Y.S., Burns, A.L., Goldsmith, P.K., Heppner, C., Park, S.Y., Chandrasekharappa, S.C., Collins, F.S., Spiegel, A.M. \& Marx, S.J. (1999) Stable overexpression of the MEN1 gene suppresses tumorigenicity of RAS-transformed cells. Oncogene, 43, 5936-5942. 
Kishi, M., Tsukada, T., Shimizu, S., Futami, H., Ito, Y., Kanbe, M., Obara, T. \& Yamaguchi, K. (1998) A large germline deletion of the MEN1 gene in a family with multiple endocrine neoplasia type 1. Japanese Journal of Cancer Research, 89, 1-5.

Krawczak, M. \& Cooper, D.N. (1991) Gene deletions causing human genetic disease: mechanisms of mutagenesis and the role of the local DNA sequence environment. Human Genetics, 86, 425441.

Larsson, C., Skogseid, B., Oberg, K., Nakamura, Y. \& Nordenskold, M. (1988) Multiple endocrine neoplasia type 1 gene maps to chromosome 11 and is lost in insulinoma. Nature, 332, 85-87.

Marx, S.J. (1998) Multiple endocrine neoplasia type 1. In: The Genetic Basis of Human Cancer (eds B. Vogelstein \& K.W. Kinzler), pp. 489506. McGraw-Hill, New York.

Orita, M., Suzuki, Y., Sekiya, T. \& Hayashi, K. (1989) Rapid and sensitive detection of point mutations and DNA polymorphisms using the polymerase chain reaction. Genomics, 5, 874-879.

Pang, J.T., Lloyd, S.E., Wooding, C., Farren, B., Pottinger, B., Harding, B., Leigh, S.E., Pook, M.A., Benham, F.J., Gillett, G.T., Taggart, R.T. \& Thakker, R.V. (1996) Genetic mapping studies of 40 loci and 23 cosmids in chromosome 11p13-11q13, and exclusion of $\mu$-calpain as the multiple endocrine neoplasia type 1 gene. Human Genetics, 97, 732-741.

Pannett, A.A.J. \& Thakker, R.V. (1999) Multiple endocrine neoplasia type 1. Endocrine-Related Cancer, 6, 449-473.

Pearce, S.H.S., Trump, D., Wooding, C., Besser, G.M., Chew, S.L., Grant, D.B., Heath, D.A., Hughes, I.A., Paterson, C.R., Whyte, M.P. \& Thakker, R.V. (1995) Calcium-sensing receptor mutations in familial benign hypercalcemia and neonatal hyperparathyroidism. Journal of Clinical Investigation, 96, 2683-2692.

Pearce, S.H.S., Williamson, C., Kifor, O., Bai, M., Coulthard, M.G., Davies, S., Lewis-Barned, N., McCredie, D., Powell, H., KendallTaylor, P., Brown, E.M. \& Thakker, R.V. (1996) A familial syndrome of hypocalcemia with hypercalciuria due to mutations in the calciumsensing receptor. New England Journal of Medicine, 335, 1115-1122.

Poncin, J., Abstract, R., Velkeniers, B., Bonduelle, M., Abramowicz, M., Legros, J.J., Verloes, A., Meurisse, M., Van Gaal, L., Verellen, C., Koulischer, L. \& Beckers, A. (1999) Mutation analysis of the MEN1 gene in Belgian patients with multiple endocrine neoplasia type 1 and related diseases. Human Mutation, 13, 54-60.

Shibata, D. (1994) Extraction of DNA from paraffin-embedded tissue for analysis by polymerase chain reaction: new tricks from an old friend. Human Pathology, 25, 561-563.

Thakker, R.V., Bouloux, P., Wooding, C., Chotai, K., Broad, P.M., Spurr, N.K., Besser, G.M. \& O'Riordan, J.L. (1989) Association of parathyroid tumors in multiple endocrine neoplasia type 1 with loss of alleles on chromosome 11. New England Journal of Medicine, 321, 218-224.

Trump, D., Farren, B., Wooding, C., Pang, J.T., Besser, G.M., Buchanan, K.D., Edwards, C.R., Heath, D.A., Jackson, C.E., Jansen, S., Lips, K., Monson, J.P., O'Halloran, D., Sampson, J., Shalet, S.M., Wheele, M.H., Zink, A. \& Thakker, R.V. (1996) Clinical studies of multiple endocrine neoplasia type 1 (MEN1). Quarterly Journal of Medicine, 89, 653-669.

Wermer, P. (1954) Genetic aspects of adenomatosis of endocrine glands. American Journal of Medicine, 16, 363-371. 